\title{
Impacts of the regulatory environment for gene editing on delivering beneficial products
}

\author{
Daniel Jenkins ${ }^{1}$ (i) $\cdot$ Raymond Dobert $^{2} \cdot$ Ana Atanassova $^{3} \cdot$ Chloe Pavely $^{4}$ \\ Received: 20 May 2021 / Accepted: 20 May 2021 / Published online: 19 August 2021 / Editor: Gary Bannon \\ (C) The Society for In Vitro Biology 2021
}

\begin{abstract}
Various genome-editing technologies have been embraced by plant breeders across the world as promising tools for the improvement of different crops to deliver consumer benefits, improve agronomic performance, and increase sustainability. The uptake of genome-editing technologies in plant breeding greatly depends on how governments regulate its use. Some major agricultural production countries have already developed regulatory approaches that enable the application of genome editing for crop improvement, while other governments are in the early stages of formulating policy. Central to the discussion is the principle of "like products should be treated in like ways" and the subsequent utilization of exclusions and exemptions from the scope of GMO regulations for these products. In some countries, the outcomes of genome editing that could also have been achieved through conventional breeding have been defined as not needing GMO regulatory oversight. In this paper, we provide a short overview of plant breeding and the history of plant biotechnology policy development, the different classes of current regulatory systems and their use of exemptions and exclusions for genome-edited plants, and the potential benefits of such approaches as it relates to achieving societal goals.
\end{abstract}

Keywords Genome editing $\cdot$ Policy $\cdot$ Regulation $\cdot$ Plant breeding $\cdot$ Societal benefits

Plant Breeding Serves as a Valuable Reference Point The plants grown today for food, feed, and other needs are the result of a long journey of crop domestication, selection, and improvements. A large number of morphological, molecular, and biochemical changes have been introduced (Doebley et al. 2006; Lenser and Theißen 2013) to significantly change the appearance, taste, and characteristics of wild progenitor plants. Breeders continuously adapt plants to diverse and changing farming practices and environments, and to the evolving needs of farmers and consumers. To achieve that, breeders use a broad range of breeding tools (Breseghello

Daniel Jenkins

djenkins@pairwise.com

1 Pairwise Plants Services, Inc., 807 East Main Street, Suite 4-100 Durham NC 27701 USA

2 Bayer Crop Science, 700 Chesterfield Parkway West St. Louis MO 63017 USA

3 BASF Business Coordination Centre - Innovation Center Gent, Technologiepark 1019052 Gent Belgium

4 Calyxt, Inc., 2800 Mount Ridge Road Roseville MN 55113 USA and Siqueira Guedes Coelho 2013; Chopra 2014) and apply them to generate and select (Walkowiak et al. 2020) plants with desired traits and characteristics. With the challenges of climate change and the demand for agricultural sustainability, as well as the raising demand for food and better nutrition, further pressure is put on plant breeding to deliver safe products in an accelerated way (Kaiser et al. 2020).

Conventional plant breeding, mostly relying on crosses and phenotypic selection, remains the main or even unique strategy for many crops, but it has been gradually complemented by improved methods (Venske et al. 2019) that increasingly incorporate knowledge of gene function and gene interactions. The currency of breeding is genetic variability, and since the discovery of DNA in the 1950s, the science of molecular biology has advanced as breeders began to understand and characterize the enormous genetic variation in plants and reliably associate genotypes with phenotypes. Today, breeders have access to a multitude of tools including genomics, as well as computer and imaging techniques, that help improve the effectiveness of plant breeding to deliver plants that reliably produce safe, nutritious, and good tasting food (American Seed Trade Association 2016; Kaiser et al. 2020). 
Because new and naturally occurring mutations yield desirable traits at a very low frequency (Ladics et al. 2015; Schnell et al. 2015), making the identification of such rare events exceedingly difficult, breeders have sought out methods to introduce genetic variability into populations (Moose and Mumm 2008) in the hopes of increasing the frequency of desirable mutations for crop improvement. Over the last century, methods making use of chemical and radiation mutagenesis, somaclonal variation, tissue culture, protoplast, cell or embryo fusion, wide and bridging crosses, haploid induction, or other methods that enable movement or rearrangement of genes within the plant's gene pool have all become common tools in a researcher's toolkit to improve crops (Chopra 2014). These methods have been well integrated into breeding practices and have contributed to the development of many new plant varieties. For example, well over 3300 crop varieties have been directly developed (International Atomic Energy Agency n.d.) by a selection of induced mutations alone, including ruby red grapefruit, seedless watermelon, and disease-resistant tomatoes (Hancock 2012) as well as many varieties of rice, wheat, and other staple crops.

Notably, with the underlying plethora of possible inherent or induced genetic variation, all these techniques have demonstrated a history of safe use, and there have not been any documented cases where breeding has resulted in the production of new toxins or allergens (Kaiser et al. 2020). The history of safe use of conventional breeding techniques including mutagenesis was already noted by the US Food and Drug Administration in their policy statement on foods derived from new plant varieties (United States Food and Drug Administration [USFDA] 1992). Over the course of centuries, and the development of countless new varieties, plant breeding has resulted in the reduction or elimination of existing natural risks. This in turn led to the view that breeding as an activity is "safe by design" (Louwaars 2019) in part because successful screening and evaluation processes have been established irrespective of the plant breeding methods employed. For plants, effective, proportionate, and targeted measures for protecting human health and the environment are in place at every stage of research and development and through commercialization and use and these measures equally apply to all products irrespective of the way they were developed (De Jong et al. 2018; United States Department of Agriculture Agricultural Marketing Service [USDA AMS n.d.). New varieties from species that are known to produce metabolites of concern (e.g., potato glycoalkaloids, cassava cyanogen, rapeseed erucic acid) are monitored and actively selected to ensure that the levels of relevant metabolites are below a threshold of concern (Kaiser et al. 2020). It is because of these long-standing practices that hundreds of new commercial varieties are introduced worldwide every year without cause for safety concerns.
With the development of the first transgenic plants in the 1980s (Bevan et al. 1983; Fraley et al. 1983; Herrera-Estrella et al. 1983), attention focused on whether this new method of genetic manipulation leads to novel risks that warranted additional assessment in comparison to those developed with earlier tools and methods. At the time, scientists and regulators agreed that in principle, recombinant DNA (rDNA) techniques and the resulting GM organisms do not result in different or greater risks than those associated with conventional genetic manipulation tools and derived organisms (National Research Council [NRC] 1989) and that the level of risk depends on the product, regardless of the way it has been developed (NRC 1987). Irrespective of these views (Conko et al. 2016), countries favored the establishment of precautionary pre-market regulations for products developed using rDNA. At an international level, this approach was reflected in the development of the Cartagena Protocol on Biosafety under the UN Convention on Biological Diversity where products of "modern biotechnology" require the performance of a specific risk assessment before environmental release. Thus, the introduction of dedicated regulatory processes for GMOs created a split in how plants products are handled from a regulatory point with a focus primarily on the manner in which they were developed (with or without the use of modern biotechnology), rather than on the actual food or environmental risk they may present (McHughen 2016).

Currently, genome editing (Zess and Begemann 2021) has become a focus of renewed discussions about the appropriate level of regulatory oversight. On one hand, genome editing is a tool of modern biotechnology, but on the other, it can result in products comparable to those developed with tools that do not trigger GMO regulatory oversight. It has also been argued that genome editing could result in genomic changes that are difficult or unlikely to be achieved with other breeding tools (Kawall et al. 2020) and that such outcomes may represent new risks. These views are contrasted by the positions of many scientific bodies (National Academies of Sciences, Engineering, Medicine 2016; European Academies' Science Advisory Council EASAC 2018; Leopoldina et al. 2019; ALLEA 2020) stating that genome editing provides not only added precision for achieving desired modifications but also a reduction in the potential for off-target or unintended changes (European Commission, DG Research and Innovation 2017; Graham et al. 2020). Divergent views-about new technologies leading to new risks on one side, and the evidence of improved control of breeding outcomes via genome editing on the other-lead to challenging regulatory discussions in many parts of the world. Earlier discussions about the appropriateness of process-based GMO regulatory triggers (Atanassova and Keiper 2018) have been reignited for genome editing. The challenge faced by regulators is how to handle plants that were developed using biotechnological tools but carry changes comparable to those that could have 
been obtained through conventional breeding, or even as a result of spontaneous changes (European Commission, DG Research and Innovation 2017).

\section{The Foundation and Principles of GMO Regulatory Regimes}

The increasing use of genome editing in plant breeding posed a challenge to regulators who, as early as 2006 (Commission on Genetic Modification 2006), began to contemplate how and whether plants and other organisms that were developed using these tools should be evaluated relative to other techniques for genetic variation that had been used widely for many years. This discernment was, from the outset, likely to pose challenges to regulators, as most technologies used to introduce genetic variation (like radiation or chemical mutagenesis, somaclonal variation, or other techniques designed to affect ploidy or allow hybridization between unrelated species) did not trigger specific pre-market regulation. In contrast, the utilization of modern biotechnology (genetic engineering) did trigger additional regulatory oversight via newly enacted GMO regulations. One of the first scientific advisory bodies (COGEM n.d.) to weigh in on the potential regulation of plants developed using "new techniques" in 2006 foresaw the conundrum between governments and product developers. They observed that "companies are only prepared to further develop some innovations when it is clear whether they are subject to the GMO legislation or not. Being bound by EU legislation, the government says it can only make this judgement when an actual application is submitted. Thus, a situation is created in which both parties are waiting for each other." This sentiment captures the importance of gaining clarity on regulatory status as a driver for innovation in breeding.

Most regulations are defined by the question of scope that lays the foundation of a regulatory scheme. The language and definitions found in regulations, normatives, or directives are typically identical to, or derived from, scope language in national laws [note: a notable exception to this construct of legislation dictating the form and scope of GMO regulation is the USA where no new legislation was enacted to support the promulgation of regulations on genetically engineered organisms and regulators had broad discretion to define the scope of their regulations and any associated exclusions or exemptions]. As such, the definition of the articles or substances that policy makers deem should be subject to pre-market regulatory assessment and approval is of paramount importance. In the area of genetic modification, the definition of terms like rDNA, transgenic, modern biotechnology, genetic modification, living modified organism (LMO), genetically modified organism (GMO), genetically engineered, and transformation event set the foundation for the scope of these regulatory systems. The scope terms were fixed in legislation and transposed into regulation beginning in the 1980s and into the early 2000s. These terms most often described the use of a narrow set of tools and processes, or presence of a type of genetic material in organisms (as well as non-living derived products that may be used for food, feed, or other regulated products) as the trigger for regulation. In addition to setting the scope of what the regulatory regimes covered ("what is a GMO") and what they excluded ("what is not a GMO"), in some instances, regulators described, by way of criteria or method descriptions, what products or techniques were exempted from the new regulations (Hamburger 2019).

An exclusion from regulation defines the organisms (and products) that are not covered by the regulation. It can be established by the definition of genetic modification, or genetic engineering, or what otherwise is defined as "regulated material" in national law or regulation. Thus, anything that is not included within the scope of the regulation is excluded and not subject to the regulation. In some instances, a regulatory scope definition explicitly calls out what a term does not mean. For example, the United States Environmental Protection Agency (EPA) has defined a class of substances that are not pesticides based on their interpretation of the scope and other definitions in the pesticide law and thus are excluded from regulation under the Federal Insecticide, Fungicide, and Rodenticide Act (FIFRA) (United States Environmental Protection Agency n.d.-a). In order for the exclusion to apply, the Agency has articulated certain criteria that must be met to be deemed a "non-pesticide." There are numerous other examples in the food and agricultural input area of exclusions that are set by law or regulatory interpretation of the law. Regulators have demonstrated varying degrees of flexibility and willingness to provide interpretation of scope or exclusion language in the law since they are attempting to discern the intent of legislators and lawmakers.

In contrast, an exemption is created by explicitly carving out certain classes of products that are within the scope of the regulation, but have characteristics, or meet certain criteria that do not warrant concern or require regulatory review. The establishment of exemptions and associated eligibility criteria (sometimes called "conditions" or "conditional exemptions") is a very important aspect of many rDNA product regulatory regimes, especially when the initial scope of the regulations is particularly expansive, and exclusions are limited or unclear.

A classic, well-analyzed example of the interplay of exclusions and exemptions can be found in the EU GMO Directive 2001/18. The directive defined (in Article 2(2)) GMO broadly covering all non-human organisms "in which the genetic material has been altered in a way that does not occur naturally by mating and/or natural recombination" (European Parliament 2001). So as to not regulate every organism whose genetic makeup was in some way selected or manipulated by human intervention, there are a series of conditions in the GMO Directive regarding techniques (i.e., human interventions) that do result in GMOs (Annex I A Part 1), and another list of techniques whose use does not result in a GMO (Annex I A 
Part 2) and are thus excluded from regulation. The GMO Directive also contains an exemption clause (Article 3) that describes (in Annex $1 \mathrm{~B}$ ) other techniques (like mutagenesis) that constitute GMOs within the meaning of Article 2(2) but are exempt from the scope of the Directive. As described further below and elsewhere (Tagliabue 2016; Zimny and Eriksson 2020) the distinctions between exclusion and exemption can have notable implications especially when the terms in the law are subjected to legal, as opposed to scientific, interpretation.

Products that meet the exemption eligibility criteria are considered to pose the same level of concern or be as safe for use as those products that are not subject to the regulation. In other words, eligibility criteria have the effect of creating a safety or protection standard that products need to meet to qualify for a pre-determined exemption. Such a mechanism achieves the goal of assuring that products on the market are acceptably safe under the law and utilizes a means other than product-specific government-directed risk/safety assessment and approval. The regulatory tool of exemptions is commonplace in many fields where regulators deem oversight to be in the interest of society but recognize that not all products within the scope of the regulation require the same degree of scrutiny. An example of conditional exemptions is EPA's criteria for "minimum risk pesticides" where the Agency has a set of six conditions that need to be met for a product to be exempted from the EPA's registration requirements (US EPA n.d.-b). Assessing the applicability of these conditions is the responsibility of the company planning to market the product (US EPA 2020). The approach taken by the EPA is similar to the United States Food and Drug Administration (FDA) regulations on food ingredients that meet the eligibility criteria (FDA 2020) to be deemed "general recognized as safe" or GRAS (Burdock and Carabin 2004). New food ingredients are subject to premarket review unless they are "generally recognized, among qualified experts, as having been adequately shown to be safe under the conditions of its intended use, or unless the use of the substance is otherwise excluded from the definition of a food additive." GRAS status can be independently determined by the ingredient developers, and for marketing and acceptance purposes GRAS determinations may also be notified to the FDA (Hanlon et al. 2017). Other examples include exemptions to FDA's food safety standards for growing, harvesting, packing, and holding foods (FDA 2017) or the allergen labeling exemptions in the Food Standard Australia New Zealand (FSANZ) regulations for certain ingredients (FSANZ 2016). Thus, consistent with other regulatory frameworks, genome-edited plant products that meet established exemption criteria by expert evaluation or government confirmation can be considered equivalent in terms of safety with products that are excluded from regulation as well as those that are reviewed and approved by a regulatory body.
Genome-Edited Products in the Context of Existing GMO

Regulations A key question that regulators around the world have tried to address as they moved to interpret the applicability, or lack of applicability, of existing GMO legislation and regulations to genome-edited organisms was "what is the intent of our GMO definition?" By extension, it was important to address what products or technologies were excluded or exempted when those GMO definitions and the scope of the GMO regulations were set. As described below, several governments in Latin America, which are either parties to the Cartagena Biosafety Protocol (BSP) to the Convention on Biological Diversity (Secretariat of the Convention on Biological Diversity 2003) or have adopted its scope (e.g., Brazil, Argentina), addressed the question of the regulation of genome editing by providing an interpretation of the phrase "possessing novel combination of genetic material" which is found in the definition of "living modified organism" (LMO) of the protocol. Under Article 3 (g) of the BSP a "living modified organism" means any living organism that possesses a novel combination of genetic material obtained through the use of modern biotechnology.

Recognizing that there remain many countries that have not yet finalized a regulatory approach or policy related to genomeedited products, the approaches already taken by regulatory agencies in classifying and evaluating genome-edited plant products fall into several discernible classes as laid out below. The regulatory landscape for genome-edited plant products (Fig. 2) is reviewed in many recent articles (Friedrichs et al. 2019; Menz et al. 2020; Schmidt et al. 2020; Turnbull et al. 2021). Given the wealth of reviews describing existing regulatory approaches, the summary below describes various approaches taken by governments in articulating exclusion or exemption criteria for genome-edited plants and the processes for gaining clarity on regulatory status. Most countries have gone through a process to evaluate their existing GMO legislation and regulations, seek public input, and then proceed with amending existing regulations or guidance.

It is also important to note that there may be multiple regulatory agencies that have developed regulatory processes to evaluate and authorize GMOs in a given country. In some countries, there may be two, three, or more agencies that are involved in assessing different aspects of food, feed, or environmental safety of new products. For a country to have a clear path that allows genome-edited plant products to come to market, each of the agencies with an existing GMO regulatory process needs to develop a clear policy and processes to apply exemptions or exclusions and confirm the regulatory status of those products.

Below, we briefly discuss examples of alternative regulatory approaches informed from initiatives in different countries, which may be considered for organisms developed using technologies such as genome editing. While there are some differences in the regulatory concepts behind the individual 
approaches, they attempt to achieve a similar goal, namely the exclusion from the scope of national GMO regulations of plant products that could have been obtained by conventional breeding methods (García-Alonso and Holt 2020).

\section{Regulatory Systems with Clearly Defined Criteria and Developer Self-determination}

- Australia/OGTR: In 2016, the Australian Office of the Gene Technology Regulator (OGTR) commenced a technical review of the Gene Technology Regulations 2001 with the objective of providing clarity about whether organisms developed using a range of new technologies are subject to regulation as GMO (Office of the Gene Technology Regulator 2016). The resulting amendments, most of which were incorporated into law in 2019 (OGTR 2019), expressly excluded "organisms modified by repair of single-strand or double-strand breaks of genomic DNA induced by site-directed nuclease, if a nucleic acid template was not added to guide repair" (commonly referred to as the SDN-1 exclusion). This exclusion was made by adding these organisms to schedule 1 which lists "organisms that are not genetically modified organisms"; such organisms might otherwise be considered within the scope of the definition of GMO provided by the Gene Technology Act 2000 (Cth) (Thygesen 2019). One of the primary rationales for excluding these organisms was that "the targeted genomic break created by a site-directed nuclease is repaired through the same mechanisms that repair naturally occurring DNA breaks, and the same range of changes to the DNA nucleotide sequence can occur as for natural mutations." Therefore, the OGTR does not require notification or consultation for such organisms to be released into the environment and it is the responsibility of proponents to ensure that the exclusion applies. While the options examined in the 2016 technical review considered broader genome-editing exclusions (e.g., template-driven DNA edits), the eventual outcome was limited by the underlying policy setting of a process-based regulatory trigger, which a subsequent review of the National Gene Technology Scheme (NGTS) concluded will be maintained (Department of Health, Commonwealth of Australia 2018). The current implementation process for the recommendations from NGTS review may provide for broader exclusions and clarity on additional tools (e.g., base or prime editing that are not nuclease-based) in the future, and/or more risk-tiered and streamlined regulatory approaches for other types of genome-editing approaches (Department of Health, Commonwealth of Australia 2020).

- US/USDA: The United States Department of Agriculture Animal (USDA) Animal and Plant Health Inspection Service (APHIS) established a set of exemptions relevant to genome-edited plants in their 2020 amendments to the 7 CFR Part 340 regulations (USDA APHIS 2020a, Section 340.1(b)). The new regulation exempts certain genome-edited plants that are within the scope of the definition of "genetically engineered" when changes in the plant genome meet any one of these criteria: (1) the genetic modification is a change resulting from cellular repair of a targeted DNA break in the absence of an externally provided repair template, (2) the genetic modification is a targeted single base-pair substitution, or (3) the genetic modification introduces a gene known to occur in the plant's gene pool, or makes changes in a targeted sequence to correspond to a known allele of such a gene or to a known structural variation present in the gene pool (Hoffman 2021). In establishing these exemption classes in plants, USDA concluded that the "exemptions are based on measures that are easily defined, are based on familiarity, and thus are meant to be limited to genetic changes that could practically be achieved by conventional breeding methods in any plant." USDA also established a mechanism to request expansion of the edits or modifications, based on the similarity of the modifications to variation that could be achieved through conventional breeding (USDA APHIS 2021). The Agency can also take action on its own to propose and add modifications that are exempted from their regulations. Similar to the approach adopted by OGTR, USDA does not require notification or verification from developers, but does provide a mechanism to request confirmation that a particular plant product meets the exemption criteria. For genome-edited plant products that do not qualify for one of the existing exemptions, USDA has implemented a simplified caseby-case determination process (termed a Regulatory Status Review) to confirm that the product does not pose a "plant pest risk."

\section{Regulatory Systems with Defined Criteria and Mechanism for Case-by-Case Regulatory Status Determinations}

- Latin American Approach: Numerous countries in Latin America have adopted a relatively consistent policy approach that set forth upstream consultative procedures to identify on a case-by-case basis if a genome-edited product is within or outside the scope of national GMO regulations. Such consultative procedure ensures regulatory flexibility to provide guidance to developers (Dederer and Hamburger 2019). In these countries, the primary determinant of whether an organism is classified as a GMO or not is the presence or absence of transgenic sequence(s) in the final product intended for introduction to the market. Products that are not in the scope of the GMO regulations remain subject to the same laws and regulations 
that are applicable to plant products developed by conventional breeding methods (see Fig. 1).

The first agency to adopt this "case-by-case absence of transgene" approach was CONABIA in Argentina. CONABIA had no directly relevant precedent to rely upon when setting out its approach on genome-edited products (referred to as NBTs) but they started with the premise that "a new regulation on NBTs should not be based on a closed list or description of particular technologies, but instead it should be framed to be flexible and able to be applied to existing or forthcoming technologies as much as possible" (Whelan and Lema 2015). This reliance on outcomes, not techniques used, to help determine regulatory status has served as a model approach in many other countries. The specific criteria CONABIA uses to assess if a product meets the definition of a GMO is whether the final product contains "a new combination of genetic material when a stable and joint insertion of one or more genes or DNA sequences that are a part of a defined genetic construct." Since the issuance of the 2015 resolution, CONABIA has conducted numerous consultations on genome-edited products, with the majority of products deemed to not be GMOs coming from local developers in a diverse set of organisms and traits (Whelan et al. 2020).

In Brazil, a normative resolution (Comissão Técnica Nacional de Biossegurança 2018) to clarify the interpretation of the 2005 National Biosafety Law as it relates to organisms developed using "innovative precision improvement techniques" (TIMP) was completed in 2018 following deliberations within National Biosafety Technical Commission (CTNBio) (Nepomuceno et al. 2020). To facilitate the determination of whether a product is excluded from the scope of the National Biosafety Law, the normative presents a non-exclusive list of example "new techniques" (in Annex 1) and articulates a series of molecular characteristics describing products that would be excluded from the biosafety law based on absence of rDNA and their similarity to conventionally bred organisms. Developers of genome-edited organisms are required to consult with CTNBio on the regulatory status of the product. The applicability of the exclusions is then determined via a case-by-case analysis by CTNBio.

The approach and establishment of exclusion criteria for genome-edited products laid out in Argentina and Brazil were closely followed in other Latin American countries, including Chile (Sánchez 2020), Colombia, Paraguay, Honduras, and Guatemala (Gatica-Arias 2020). Each of these countries has released final resolutions or regulations clarifying the criteria for exclusions or exemptions that may be applicable to genome-edited organisms (Menz et al. 2020). This consistency in approach and criteria for exclusion from GMO regulations across Latin America provides an important regional advantage in terms of supporting multi-lateral or regional regulatory cooperation and an environment conducive to innovative

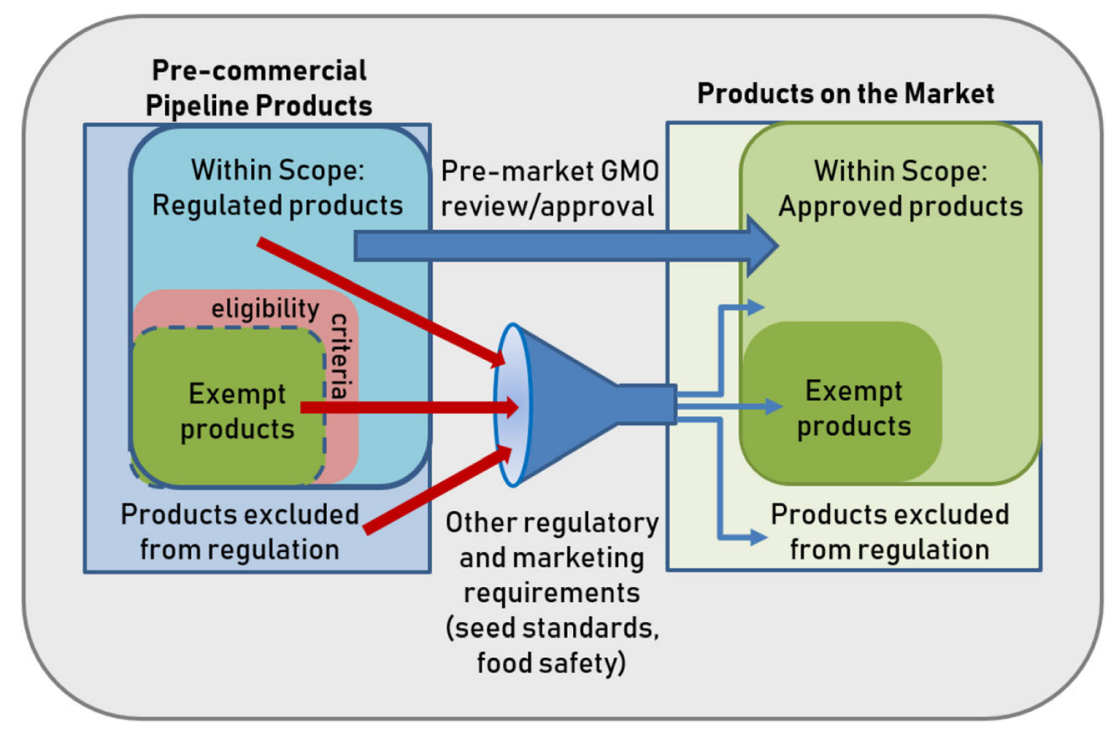

Figure 1. Schematic diagram illustrating the general relationship between regulatory scope, exclusions, and exemptions, and the role of eligibility criteria for plant products. Products that are, by definition, within the scope of the regulations may either be evaluated by a regulatory body and approved to gain market access or determined to meet defined exemption criteria ("eligibility criteria") and considered to meet the same safety or protection targets as products that have been approved. It should be noted that all products whether they are "excluded from regulation," exempted or go through a pre-market approval process would be subject to other regulatory requirements under other authorities (e.g., seed testing/quality standards, food safety standards). Depending on the country/region, a myriad of post-market safety and marketing requirements are also likely to be applicable to all products (Institute of Medicine (US) and National Research Council (US) 1998). 
product development and deployment. This regional cooperation was articulated in a 2019 Southern Agricultural Council (Consejo Agropecuario del Sur [CAS]) "Declaration of Gene Editing Techniques" signed by the Ministers of Agriculture from Argentina, Brazil, Chile, Paraguay, and Uruguay (Southern Agricultural Council (CAS) 2019). It is also of note that the first country with a formal policy on genome-edited plants in Africa, Nigeria, has taken a case-by-case approach clarifying the types of modifications (lacking rDNA in the final product) that would not require a GMO evaluation in a manner similar (USDA Foreign Agricultural Service [FAS] 2021) to what has been adopted in several Latin American countries.

- Japan: There are three regulatory agencies overseeing different aspects of use of GMOs in Japan, the Ministry of the Environment (MOE), the Ministry of Agriculture, Forestry, and Fisheries (MAFF), and the Ministry of Health, Labor and Welfare (MHLW). These agencies have clarified when the existing GMO regulations apply to genome-edited products and when they do not. This clarification is based on an interpretation of the scope of the GMO legislation. Under the MOE policy finalized in 2019 (USDA FAS 2019a), and later accompanied by implementing guidelines issued by MAFF (USDA FAS $2019 b$ ), certain categories of genome-edited plants do not require review under MOE's GMO regulations (also called the "Cartagena Law"), once determined to fall outside the scope of the definition of a "living modified organism" (LMO) (Tsuda et al. 2019). Specifically, the policy stated that genome-edited organisms where "extracellularly processed nucleic acid is not transferred" into the plant or when "it has been confirmed that no nucleic acid or a replicated product thereof remains in the finally obtained organism," the product is not considered an LMO. Furthermore, if the inserted "extracellularly processed" nucleic acid is from the same species (referred to as "self-cloning"), or from a species that can exchange nucleic acids with the species that has been edited (e.g., from a sexually compatible species) that organism is also not considered to be an LMO. Thus, from a practical standpoint, this policy excludes plants that do not have integrations of "extracellularly processed nucleic acids" (i.e., transgenes), and plants that solely contain genetic material that comes from the same or sexually compatible species.

MHLW clarified its policy stance for foods derived from genome-edited plants in 2019, outlining the types of genome-edited food products that would "present the same level of risk as a food product from conventional breeding" and thus not be subject to the GMO safety assessment process (USDA FAS 2019c). The criteria set forth by MHLW for products that do not require a GMO safety assessment include (1) absence of transgenic ("foreign") genes and/or fragments in the final product and (2) changes induced by an enzyme recognizing a specific base sequence resulting in (a) base-pair deletions; (b) substitution; (c) naturally occurring gene deletion; and/or (d) insertion of one to several base pairs (USDA FAS 2019d). Notification to MHLW with relevant information by developers is expected to confirm the applicability of the criteria to specific products intended for use as food.

The status of feeds derived from genome-edited plants was clarified by MAFF in its 2020 guidelines (USDA FAS 2020). The criteria for exemption from the GMO regulations and processes to notify the agency are closely aligned with the approach taken by MHLW related to food products. It is noteworthy that the completion of policies and relevant guidance in Japan in 2020 was followed by notification and confirmation in late 2020, of regulatory status of a compositionally enhanced tomato (with elevated levels of gamma-aminobutyric acid) co-developed by a Japanese firm (Sanatech) and a leading Japanese university (Tsukuba University). The tomatoes are expected to be available for home garden use in 2021, making it the first commercial genome-edited product in Japan.

\section{Countries with Judicial Rulings Determining that New} Modification Techniques Are Not Excluded or Exempt In contrast to the countries described above, the regulatory status of genome-edited plants in the following two jurisdictions was not set by scientific advice and public input followed by regulatory agency interpretation and policy implementation, but by judicial interpretation of existing GMO legislation. In both instances, the status of genome-edited products was inferred from interpretations provided by courts on specific processbased definitions of the term GMO that was laid out in legislation that pre-dated the widespread use of genome-editing techniques.

- European Union: A great deal has been written regarding the legal interpretation of the EU GMO Directive (2001/18/ EC) by the European Court of Justice (ECJ) in July 2018 (Eriksson et al. 2019; Plant Genetic Resources International Platform 2019; Sowa et al. 2021). In brief, the court ruled (European Court of Justice 2018) that mutagenesis methods not widely used in the development of products prior to 2001 do not qualify for the explicit exemption afforded to mutagenesis techniques. The ECJ ruling placed products developed using "new" techniques like genome editing within the scope of the GMO directive (Van der Meer et al. 2020; Vives-Vallés and Collonnier 2020). This interpretation places stronger weight on the technology or techniques used in determining a products regulatory status. Under the ECJ interpretation, two organisms with an identical genetic 
makeup, expressing an identical set of characteristics and the same safety profile, but developed using techniques in practice either prior to 2001, or after 2001, would be treated differently under the law. This approach violates basic "equal treatment" principles that products that are the same should be treated in an equivalent manner under the law.

- New Zealand: The Environmental Protection Authority (EPA) administers the Hazardous Substances and New Organisms Act of 1996 (HSNO Act) which includes GM organisms. The general scope of the "new organism" definition in the HSNO Act includes "a genetically modified organism," which is further defined in Section 2A as any organisms where the genes or genetic material has been modified by in vitro techniques, with the term "in vitro technique" undefined (Hazardous Substances and New Organisms Act 1996 1996). The HSNO Act includes specific exclusions and, as in the EU, further exclusions are provided in a list of "organisms not genetically modified" in the Hazardous Substances and New Organism Regulations 1998. Applicants can request a determination from the EPA whether or not an organism is a "new organism" under the Act (Hazardous Substances and New Organisms Act 1996 1996; Section 2A, section 26). In 2012, a developer made such an application concerning a genome-edited organism with a targeted mutation, and the EPA's determination was that certain applications of genome editing were sufficiently similar to the exempted process of chemical mutagenesis, and such organisms were not GMOs (Fritsche et al. 2018). In pre-dating the genomeediting policy in Argentina adopted in 2015, for a brief period, New Zealand was the first country where a regulatory agency was willing to determine that certain types of genome edits could be exempt from GMO regulation. But that status was short-lived as this determination was challenged, and the legal interpretation subsequently provided by New Zealand's High Court in 2014 made it clear that the organism must be expressly captured by the "organisms not genetically modified" list and that the EPA was exceeding its powers by making interpretations that expanded its scope (Kershen 2015). The ruling by the Court in New Zealand was a further example that when processes define either the scope or exclusions in GMO regulations, it is very challenging for such a 2 to adapt to new technologies and processes. The Regulations were subsequently amended in 2016 to expressly limit the scope of mutagenesis exclusions to chemical or radiation treatments that were in use on or before 29 July 1998 (Hazardous Substances and New Organisms (Organisms Not Genetically Modified) Regulations 1998, amended 2016).
Looking Ahead: What Is Still to Come for Genome-Edited Plant Regulation? Regulatory alignment and consistency will be important for the use of technologies like genome editing to be broadly adopted and applied in a manner akin to the widespread use of common plant breeding techniques like classical mutagenesis and other techniques used to introduce genetic variation into plant genomes. It has been noted and clearly articulated in the literature (Menz et al. 2020; Entine et al. 2021; Turnbull et al. 2021) that currently, there is a lack of regulatory harmonization and consistency around the world with regard to the status of genome-edited plant products. At this point, there are emerging general trends (certain edits like deletions are generally considered to be exempt from GMO regulations), but there is clearly more global "disharmony" than harmonization in the regulatory treatment of genomeedited plant products. As illustrated in Fig. 2, there are many regions and countries with significant agricultural productivity and human population (e.g., China, India, sub-Saharan Africa (Komen et al. 2020), Russia, Mexico) that are currently evaluating their options and deciding on a path forward in setting policies and practices related to genome-edited organisms. The Canadian approach toward genome-edited products also remains under development as of early 2021 with a proposed approach put forth by Health Canada in March 2021 (Health Canada 2021). Canada has been the only country that explicitly designed its regulations around a "product-based" approach to assess "novelty" in plants and derived food and feed regardless of how the novelty was developed (Ellens et al. 2019). With this product-based focus, Canadian agencies have been challenged to contemplate how to address novelty in the context of techniques like genome editing that may not create novel genetic combinations. At the other end of the spectrum, in the EU the European Commission study report (European Commission and SWD 2021) on new genomic techniques (NGTs) released in April 2021 recognizes that strictly process-based regulations are not "fit for purpose" and that there is a need for regulations to be adapted to account for scientific and technological progress. The recognition in the report that "it may not be justified to apply different levels of regulatory oversight to similar products with similar levels of risk, as is the case for plants conventionally bred and obtained from certain NGTs" is a good summary of the challenge that the regulators are trying to resolve.

Given the global interconnectedness of food and grain markets and the critical need to move material between countries during the development and production of seed and plant products, regulatory disharmony will, in the long run, have negative inhibitory effects on the utilization of these tools to develop new plant varieties. As such, the inability for breeders and crop developers to use "all the tools in the toolbox" may mean a lost opportunity to continue to develop crops and agricultural production systems that meet critical societal needs. 
Impacts of Sound Regulatory Policy on Delivering Societal Benefits In the coming decades, the global agricultural system must find ways to meet pressing but often competing needs. Farmers must produce enough food for a population that is expected to reach nearly 10 billion people by 2050 . Employing around 2 billion people today (International Labour Organization n.d.), agriculture must continue to be an engine of inclusive economic and social development that contributes to poverty reduction, even as many small-scale farmers transition into other forms of employment. At the same time, agriculture must lighten its environmental footprint. The impacts of agriculture are large and growing, including aspects of land degradation, water scarcity, and climate change (Searchinger et al. 2019; Crippa et al. 2021). Finally, a renewed focus on nutrition is paramount: recent estimates of the impact of our global nutritional and diet state that 11 million deaths and 255 million disability-adjusted lifeyears were attributable to dietary risk factors (GBD 2017 Diet Collaborators 2019). In short, the world must improve the way it produces and consumes food. Given the magnitude of these challenges, all tools and forms of agriculture have value in contributing to a sustainable future. The development of plant varieties employing modern breeding techniques, such as genome editing, could be among the most impactful and efficient approaches to address these shared goals.

To achieve these goals, multiple elements must be addressed quickly and effectively to generate an environment that allows innovative tools like genome editing to be broadly adopted. Elements such as trust among consumers and stakeholders to help gain acceptance, appropriate market incentives, and clear policy and regulations are all of critical importance (Herrero et al. 2020). However, if clear, workable policies and regulations are not in place, then the need for the "license to operate" elements are generally moot. Appropriate policies and regulations are the foundation that enables initial and stable investment in research and development activities that are needed to bring products to fruition. The prospect of tangible commercial products that flow from this foundation will then serve as the basis of downstream discussions in these other areas.

In this section, we seek to illustrate the benefits that sound policy is already having, and can continue to have, in positively changing the way we produce and consume food through the application of plant genome editing. As a framework, we consider the United Nations 2030 Sustainable Development Goals (United Nations 2015). These 17 Sustainable Development Goals (SDGs) were finalized in September of 2015 by a global coalition to "meet the needs of the present without compromising the ability of future generations to meet their own needs" and are based on three interconnected principal elements: economic growth, social inclusion, and environmental protection. It is a reasonable assumption that most, if not all, stakeholders involved in the nexus between agriculture, technology, and society share these goals at least at a high level. Nonetheless, the recent 2020 UN update report on progress against these targets shows that even before the COVID-19 pandemic, progress was "at best uneven" (United Nations 2020). Global efforts to date have been insufficient to make the changes required in the necessary amount of time. This has led to a call for a "Decade of Action" with the UN Secretary-General calling for urgent advancement on three levels, including inter alia: global action to secure smarter solutions; local action transitioning policies and regulatory frameworks; and people action, including civil society, the media, the private sector, academia, and other stakeholders, to push for the required transformations. Given the UN's recognition that "food systems connect to every sustainable development goal," there is a very real opportunity for sound genome-editing policy to have broad impacts toward these goals over the next decade.

However, transformative changes to "food systems" will be difficult to enact if there are a limited number of enterprises that are able to garner the resources needed to develop and bring new products to market. Disproportionately restrictive and burdensome regulations, such as the current GMO regulations, will result in a familiar conundrum: a few companies focused on a handful of large acreage, globally grown crops, mostly on only broadly applicable traits. This sentiment is echoed in the aforementioned European Commission study report (European Commission and SWD 2021) where they summarized the view that genome-editing techniques afford "an opportunity for SMEs (small and medium enterprises) to develop minor, niche, or orphan crops, and special traits in plants, in response to local needs, to move toward more sustainable agri-food production, stress-tolerant, and diseaseresistant varieties, and a reduced use of plant protection products." For these opportunities to be realized appropriate policy changes are necessary. As mentioned above, under the policies enacted in Argentina, many products developed with the use of genome editing are not GMOs, and thus not subject to GMO regulatory requirements. In the four years following the implementation of the Argentinian policy, an analysis showed that genome-edited products are pursued by a more diverse group of developers, largely comprised of small- and mediumsized companies and public sector researchers, and are more diverse in terms of crops as well as traits (Whelan et al. 2020). While $90 \%$ of the GMOs going through a regulatory process in Argentina were developed by multinationals, $59 \%$ of the genome-edited product determination requests were made by local companies and public sector researchers. In addition, GMO submissions were predominantly for herbicide tolerance and insect protection traits in row crops, while genomeedited product consultations spanned a much broader range of traits including those for increased productivity and consumer preference, in crops that also included fruits and vegetables and ornamental plants (Whelan et al. 2020). 


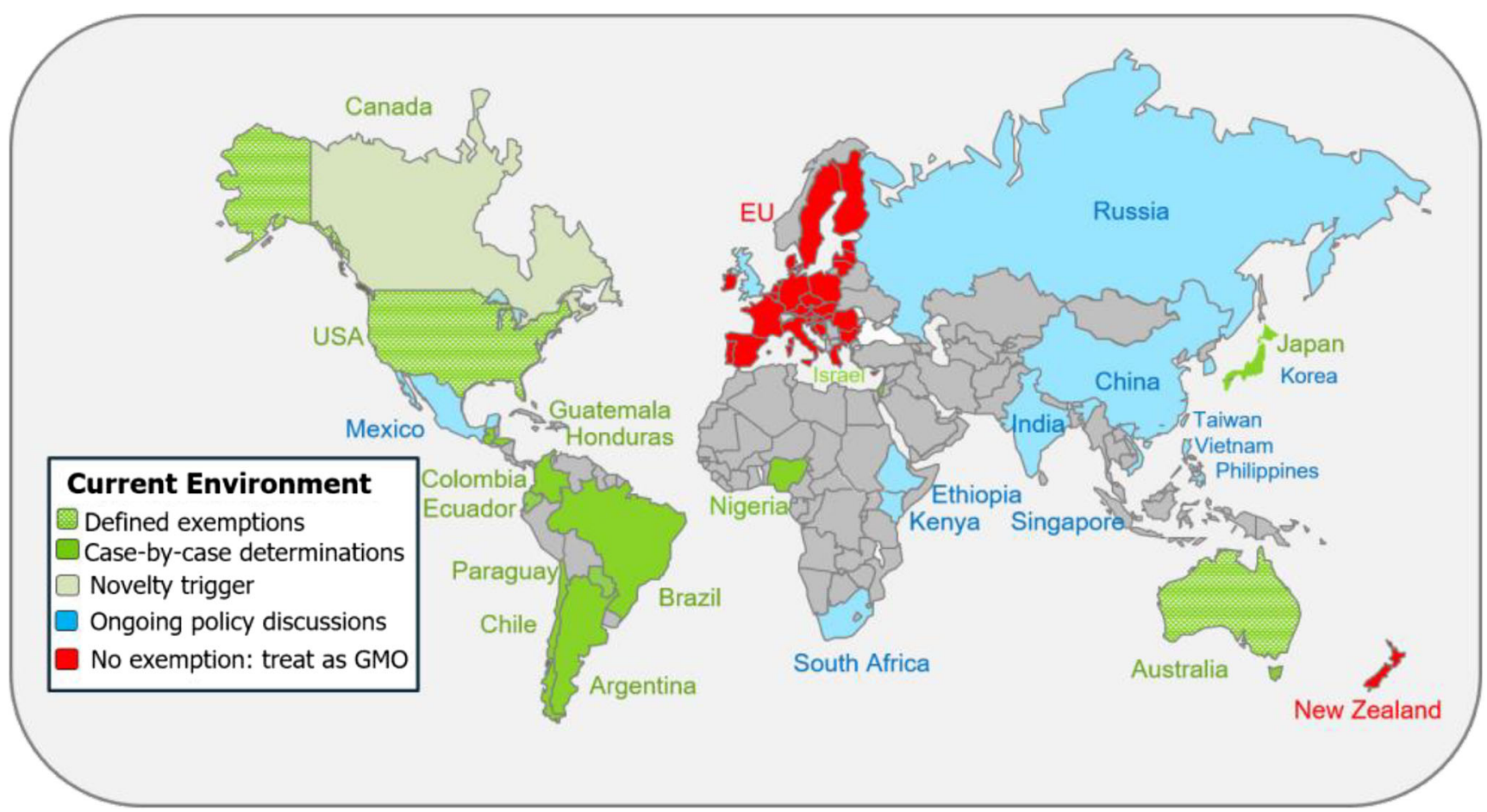

Figure 2. World map showing the current regulatory policy landscape related to genome-edited plant products. The key indicates which countries/regions have regulatory policies and processes already in place,

Importantly, the widespread use and adoption of a set of breeding tools that are capable of efficiently and affordably working across species, varieties, and attributes, can help move us from euphemisms like "uneven progress" to actual progress in a timeframe that keeps pace with population and climate challenges. While plant breeding innovations can contribute to the achievement of different SDG goals and targets, we focus on selected examples of genome-editing applications in plant breeding that can directly address targets under four specific SDGs listed below (Table 1).

Zero Hunger This goal aims to end hunger, achieve food security and improved nutrition, and promote sustainable agriculture. After decades of decline, 2015 marked a reversal with a slight increase in the number of people suffering from chronic undernourishment, with current estimates stating that nearly 690 million people are hungry, up by nearly 60 million in five years, and nearly one in ten people in the world suffered severe levels of food insecurity (United Nations n.d.-a; Food and Agricultural Organization, IFAD, UNICEF, WFP, WHO 2020). Profound changes to the global food and agriculture system are needed, including production and distribution challenges, if we are to nourish the people who are hungry today, while meeting the challenge of a global population growing by an additional 2 billion people by 2050 that needs an increase of food production by over 50\% (Searchinger et al. 2019). which are currently having policy discussions, and areas where court rulings have determined that GMO regulations are applicable to genome-edited plants.
Genome editing of plants offers strong potential to address these issues. Unlike conventional breeding approaches, these new breeding techniques offer an efficient means to generate optimized germplasm. In the past few years, genome editing has been used to improve a multitude of crop characteristics and there are several examples of products being developed that can substantially contribute to reducing hunger. Rice, wheat, and maize are the world's three leading food crops and together they provide more than $42 \%$ of all calories consumed by the entire human population (Searchinger et al. 2019). In maize, genome-edited lines with targeted edits in the native zmm 28 gene promoter and in FEA3, resulting in plants with higher yield and kernels per row, were moved through regulatory clearance in the USA (USDA APHIS $2020 \mathrm{~b}$ ). With billions of people depending on rice for $20 \%$ of their daily calories, it is the staple food of more than half of the world's population (Ricepedia n.d.). Recent academic research has shown that editing the rice LOGL5 gene enhanced grain yield in a variety of environmental conditions (Zhu et al. 2020). Other examples in rice include edits involved in regulating panicle size, grain size, and grain weight that have all provided increased yields (Stanic et al. 2021).

There are also potential productivity benefits in specialty crops. For example, a naturally occurring trait in strawberries that causes them to produce fruit for a significantly longer period was recently exempted from regulation (USDA APHIS 2020c). Similarly, use of editing for achieving increased yield of fruit 
Table 1. Summary of potential genome-edited crop products. An " $x$ " indicates relevance to a United Nations Sustainable Development Goal (2 Zero Hunger, 3 Good Health and Well-Being, 13 Climate Action, 15 Life on Land) for those products

\begin{tabular}{|c|c|c|c|c|}
\hline Species & 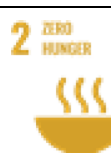 & 3 and Weal-BENG & 13 ACRAON & 15 Uft \\
\hline Alfalfa & & & & $x$ \\
\hline Apples & $x$ & $x$ & $x$ & $x$ \\
\hline Avocado & $x$ & $x$ & & \\
\hline Bananas & $x$ & $x$ & & \\
\hline Berries & $x$ & $x$ & & \\
\hline Canola & $x$ & & $x$ & $x$ \\
\hline Cassava & $x$ & $x$ & & \\
\hline Citrus & $x$ & $x$ & & \\
\hline Cotton & $x$ & & $x$ & $x$ \\
\hline Dandelion & & & $x$ & \\
\hline Grapes & $x$ & $x$ & & \\
\hline Hemp & & $x$ & $x$ & $x$ \\
\hline Leafy Greens & $x$ & $x$ & & \\
\hline Maize & $x$ & & $x$ & $x$ \\
\hline Peanuts & $x$ & $x$ & & \\
\hline Peas & $x$ & $x$ & $x$ & \\
\hline Pennycress & & & $x$ & $x$ \\
\hline Poplar & & & $x$ & $x$ \\
\hline Potato & $x$ & $x$ & $x$ & $x$ \\
\hline Rice & $x$ & $x$ & $x$ & $x$ \\
\hline Soybean & $x$ & $x$ & $x$ & $x$ \\
\hline Tomato & $x$ & $x$ & $x$ & $x$ \\
\hline Wheat & $x$ & $x$ & & \\
\hline
\end{tabular}

crops through edits of genes involved in meristem size has been reported (Rodriguez-Leal et al. 2017; Yuste-Lisbona et al. 2020). Reductions in food waste can be addressed by traits that prolong shelf life (Cohen 2019) or reduce darkening and discoloration in fruits and vegetables that are perceived as undesirable by both consumers and processers. To date, USDA has exempted five potential genome-edited products that are being developed to address this issue (potatoes and avocados with low polyphenol oxidase (PPO)) (USDA APHIS 2020d, 2020e, 2020f, 2020g, 2020h, 2020i).

Good Health and Well-being This SDG goal is largely focused on improvement in the medical field and delivery of healthcare more universally. Genome editing has been applied in medicinal plants to further our understanding of important biosynthetic pathways of secondary metabolites to possibly enhance their application and potentially improve their yield and quality (Karkute et al. 2017). In addition to plants that can provide medicinal benefits, nutrition, and improved diets also play a critical role in good health and well-being. Poor dietary habits are associated with a range of chronic diseases and are a major contributor to non-communicable disease-related mortality worldwide (GBD 2017 Diet Collaborators 2019).

There are several applications of genome editing in crops that may support more healthy diets. Fruit and vegetable crops are important for a healthy diet, but they have had less genetic improvement compared to other crops due to the difficulty in breeding many of them. Currently, only 15 out of approximately 30,000 edible plants contribute an estimated $70 \%$ of our calories (Fernie and Yan 2019). Pairwise, a startup company focused on using genome editing in fruits and vegetables, has recently advanced a leafy green through the US regulatory exemption process (USDA APHIS 2020j). Mustard greens (Brassica juncea (L.)) are among the most nutrient- 
dense leafy green vegetable available for consumers and are characterized by a wide variation of leaf traits such as color, size, texture, and heading morphology. When eaten fresh, they are pungent due to the presence of natural defense compounds which are produced in response to herbivory. Consequently, mustard greens are typically either cooked to minimize pungency, or consumed fresh in smaller quantities or as baby greens. Pairwise has knocked out multiple homologs of the gene responsible for producing these pungent compounds resulting in an improved flavor and highly nutritious mustard green intended for fresh-market consumption. Another freshmarket health-focused application of genome editing is the gene-edited tomato with an increased amount of naturally occurring $\gamma$-aminobutyric acid (GABA) developed by the Japanese company Sanatech that was recently determined by USDA to not be subject to their regulations and the Japanese Ministry of Health, Labor and Welfare (MHLW 2020) confirmed that the product is not a GMO and can be marketed. GABA is a non-protein amino acid, widely found in bacteria, which has been shown to lower blood pressure in humans, thus providing a potentially important health benefit (USDA APHIS 2020k).

Another important specialty crop genome editing is being applied to that could impact good health and well-being is cassava. Cassava (a.k.a. yuca, manioc, muhogo, or tapioca) is one of the most important root crops, mainly due to its tolerance for drought and marginal soils, with approximately a billion people relying on it as a source of calories, primarily in Africa and the tropics. However, cassava roots naturally produce a precursor of cyanide. Over time, consuming this cyanogenic compound can have effects that range from cognitive problems to sudden and irreversible paralysis of the legs. The cyanide precursor can be removed through processing, a burden that mainly falls on women, but in many areas of subSaharan Africa that have experienced drought, famine, and instability, proper processing typically does not occur. Given the precision and efficiency of genome editing, it is a nearly ideal approach to address this problem as it is impractical to use slow conventional breeding methods that would also disturb other preferred traits (Innovative Genomics Institute n.d.).

In row crops, researchers have developed lower $\alpha$-gliadin wheat. Wheat is well known to contain proteins that trigger hypersensitivity in individuals with Coeliac disease through the ingestion of gluten proteins like $\alpha$-gliadin. Using genome editing, multiple lines have been generated, all showing large reduction in these causative peptides (Sánchez-León et al. 2018). Calyxt, a plant-based technology company, has gained exemption determinations for high oleic low linolenic soybean (Haun et al. 2014; USDA APHIS 20201), high fiber wheat (USDA APHIS $2020 \mathrm{~m}$ ), and low acrylamide potato (USDA APHIS 2014; Clasen et al. 2016) for improved storage and health benefits as well as food safety clearance from FDA (US Food and Drug Administration n.d.). Finally, genome editing has also been used to develop rice lines containing higher amylose content. Amylose is a resistant starch and thus not digestible in the small intestine, so it is passed on to the large intestine and therefore may reduce the risk of health issues such as diabetes (Sun et al. 2017).

Climate Action This UN Sustainability Goal seeks to "take urgent action to combat climate change and its impact." Improvements to crop plants in terms of yield gains, as well as traits that can build upon their natural ability to capture carbon, or to serve as alternatives to fossil fuels or animalbased proteins, are critical to achieving this goal. Disease and pest resistance are of particular importance because the changing climate may lead to increased pressure from plant pathogens and pests, with some estimating that yield losses in corn, rice, and wheat to insects could increase by 10 to $25 \%$ for every $1{ }^{\circ} \mathrm{C}$ of rising global temperatures (Deutsch et al. 2018).

Improvement of crops to mitigate the impacts of climate change, has been constrained by the limitations of conventional breeding. Pairing increased genome knowledge with genome editing is an encouraging potential solution to these goals (Fernie and Yan 2019). This is in part why programs such as USDA's Agricultural Genome to Phenome Initiative n.d. (AG2PI) have been initiated (AG2PI n.d.). There are multiple efforts across crops to increase yield and improve performance in response to stress (Ahmar et al. 2020; Kitomi et al. 2020). For example, modern tomato cultivars are strongly affected by environmental stress, while other edible Solanaceae species that remain untapped due to being poorly adapted for cultivation are generally resilient and resistant to disease. Multiple studies have demonstrated that with a small number of edits these wild species can be domesticated (Soyk et al. 2016; Rodriguez-Leal et al. 2017; Soyk et al. 2017). These kinds of changes would take conventional breeding decades to achieve and may provide a wider selection of varieties more suitable to changing environmental conditions.

Researchers are also looking for ways to optimize plants' natural ability to capture and store carbon. Using CRISPR as a research tool, they were able to identify and demonstrate the EXOCYST70A3 gene as a strong modulator of root system architecture in a model plant system. This discovery could have significant impacts on drought tolerance and carbon capture advancement across a wide variety of plants (Ogura et al. 2019) if appropriate regulatory systems are in place. Genome editing was used to develop new varieties of the cover crop pennycress that has improved quality characteristics to function as a low carbon intensity feedstock for food, bioenergy, and animal feed (CoverCress Inc n.d.) and potential products from this developer have been exempted by USDA (USDA APHIS 2020n, 2020o).

There are also several interesting areas of research to further reduce our dependence on fossil fuels. One is rubber 
production, where fossil fuel is a common feedstock. A species of dandelion (Taraxacum kok-saghyz) produces high molecular weight rubber in its roots and has the potential to serve as an alternative source of natural rubber. Researchers were able to create a high efficiency system using CRISPR/Cas9 which may facilitate the use of this species as a viable rubber crop (Iaffaldano et al. 2016).

Genome editing has been proposed as a way to shorten the long breeding cycles of trees and tree-like species and for the development of specific valuable characteristics that are challenging to achieve using traditional methods. Genome editing was recently used successfully in poplars (Zhou et al. 2015) and is being applied to solve devastating problems of disease in the production of a variety of different fruits. For example, genome editing has been used to develop citrus trees resistant to citrus canker disease (Peng et al. 2017) and Cavendish bananas resistant to Panama disease (Queensland University of Technology n.d.), and the public sector in Brazil has been working to develop citrus trees resistant to citrus greening (Maliszewski 2021). Other advancements include gene knockouts to lessen susceptibility to powdery mildew and fire blight disease in grape and apple protoplasts (Malnoy et al. 2016).

Life on Land This goal aims to protect, restore, and promote sustainable use of terrestrial ecosystems, sustainably manage forests, combat desertification, and halt and reverse land degradation and halt biodiversity loss. According to the United Nations: "Human activity has altered almost 75 per cent of the earth's surface, squeezing wildlife and nature into an eversmaller corner of the planet." Around 1 million animal and plant species are threatened with extinction-many within decades - according to the 2019 Global Assessment Report on Biodiversity and Ecosystem Service calling for transformative changes to restore and protect nature. Plants play an important part in these discussions as they are a major class of organisms that can provide habitat and serve as the basis of food webs and ecologies throughout the world, yet can at times also be disruptive to these ecological roles due to their cultivation footprint.

For example, the expansion of palm oil cultivation has become controversial, due to the associated land use change and resulting environmental impacts. Current estimates place the number of species threatened by expanded palm oil cultivation over 300 (Meijaard et al. 2020). Calyxt is working on a high saturated fat soybean that may serve as an alternative to palm oil (Calyxt n.d.-a). Such an alternative may present a source of vegetable oil with characteristics similar to palm oil, while providing a more sustainable source of this ingredient. Another approach for making better use of terrestrial ecosystems is to improve animal feed efficiency with products such as improved digestibility alfalfa currently developed by S\&W Seed Company (Mickelson 2020). Finally, hemp is a crop with considerable untapped potential for bringing plantbased and sustainable solutions for foods, materials, and nutraceuticals. Hemp is historically a non-domesticated crop poorly adapted for broad acre production. Development to stabilize and optimize hemp seed genetics is underway (Calyxt n.d.-b) to unleash the significant potential it has as a crop for addressing these sustainability challenges.

As the land and water resources needed to support global meat consumption at its current rate become less available, many scientists and food entrepreneurs are looking to create realistic plant-based alternatives that mimic the flavor, texture, and nutrition of meat. Startups like Impossible Foods and Beyond Meat have seized this opportunity in recent years to address this issue and meet grower consumer demand for meat alternatives. Peas are a protein-rich food that are an attractive contributor to the development of these products. However, pea protein's flavor profile can be problematic for consumers. Students at the University of California Berkeley have initiated a startup ("CRISPea"), using CRISPR to "knock out" the gene responsible for pea protein's bitter flavor (Lynn 2018).

\section{Conclusions}

From a regulatory and policy standpoint, we find ourselves at a key moment for genome editing in plants. We are at the nexus of urgent and pressing sustainability issues worldwide, at a time when we have modern breeding techniques that can be applied broadly and precisely to crops, which can have meaningful impact across a large set of commonly shared goals. The European Commission study report (European Commission and SWD 2021) underlined the potential of new genomic techniques (genome editing) and the products that can be developed with these to contribute to sustainable agri-food systems in line with the objectives of the European Green Deal and "Farm to Fork Strategy." This potential can only be fully realized with an enabling regulatory environment that duly considers the increased precision and efficiency of the tools.

The regulatory policy trends for genome-edited plants appear to be taking a different direction from the regulatory choices made over the past 30 years for modern biotechnology. The implementation of enabling regulatory policies for genome-edited products appears to already have had a democratizing effect in terms of types of applications and range of developers. This is in part due to governments taking a science-based and risk proportionate approach in applying established and commonly practiced regulatory procedures, such as exclusions or exemptions, when justified. Such paradigms are justified when applying the oft-cited principles that product characteristics, not the process used, should drive the need for a safety assessment and like products should be treated in like ways. It is only with sound, objective, and equitable 
regulations that research, investment, and development in plant breeding improvement can occur. If the hurdles are disproportionate, innovation will stall at a time when we cannot afford to stand still if agriculture is to achieve global sustainability goals.

Acknowledgements The authors of this paper are grateful to Ms Lysiane Snoeck for help with the references.

\section{Declarations}

Conflict of interest The authors of this paper are employees of Pairwise Plants Services, Inc., Bayer Crop Science, BASF, or Calyxt, which are companies involved in the development of genome-editing tools and edited plants.

\section{References}

Agricultural Genome to Phenome Initiative (n.d.) https://www.ag2pi. org/. Cited 12 Apr 2021

Ahmar S, Gill RA, Jung K-H, Faheem A, Qasim MU, Mubeen M, Zhou W (2020) Conventional and molecular techniques from simple breeding to speed breeding in crop plants: recent advances and future outlook. Int. J. Mol. Sci. 21(7):2590. https://doi.org/10.3390/ ijms 21072590

ALLEA (2020) lead authors Dima O, Bocken H, Custers R, Inzse D, Puigdomenech P. Genome editing for crop improvement. Symposium Summary. Berlin, doi: https://doi.org/10.26356/genediting-crop

American Seed Trade Association (2016) Common practices of plant breeders. American Seed Trade Association, Alexandria, VA. https://www.betterseed.org/wp-content/uploads/CommonPractices-of-Plant-Breeders-Formatted.docx-2.pdf.

Atanassova A, Keiper F (2018) Plant breeding innovation: Aa global regulatory perspective. Cereal Chem 95:8-16. https://doi.org/10. 1002/cche. 10021

Bevan MW, Flavell RB, Chilton MD (1983) A chimaeric antibiotic resistance gene as a selectable marker for plant cell transformation. Nature 304:184-187

Breseghello F, Siqueira Guedes Coelho A (2013) Traditional and modern plant breeding methods with examples in rice (Oryza sativa L.). Journal of Agricultural and Food Chemistry 61(35):8277-8286. https://doi.org/10.1021/jf305531j

Burdock GA, Carabin IG (2004) Generally recognized as safe (GRAS): history and description. Tox. Lett. 150(1):3-18. https://doi.org/10. 1016/j.toxlet.2003.07.004

Calyxt (n.d.-a) High saturated fat soybean for palm alternative https:// calyxt.com/innovation-pipeline/\#hfaq-post-6439. Cited 12 Apr 2021

Calyxt (n.d.-b) Hemp https://calyxt.com/innovation-pipeline/\#hfaq-post6437. Cited 12 Apr 2021

Chopra S (2014) Techniques and tools of modern plant breeding: field crops. In: Ricroch A, Chopra S, Fleischer S (eds) Plant Biotechnology. Springer, Cham., pp 25-33. https://doi.org/10. 1007/978-3-319-06892-3 3

Clasen BM, Stoddard TJ, Luo S, Demorest ZL, Li J, Cedrone F, Tibebu R, Davison S, Ray EE, Daulhac A, Coffman A, Yabandith A, Retterath A, Haun W, Baltes NJ, Mathis L, Voytas DF, Zhang F (2016) Improving cold storage and processing traits in potato through targeted gene knockout. Plant Biotechnol J 14:169-176. https://doi.org/10.1111/pbi.12370

COGEM Report CGM/061024-02. (n.d.) https://cogem.net/app/uploads/ 2019/07/CGM061024-02-new-techniques-in-plantbiotechnology. pdf

Cohen J (2019) To feed its 1.4 billion, China bets big on genome editing of crops. https://www.sciencemag.org/news/2019/07/feed-its-14billion-china-bets-big-genome-editing-crops. Cited 12 Apr 2021

Comissão Técnica Nacional de Biossegurança (2018) Resolução Normativa $\mathrm{N}^{\circ} 16$, de 15 de janeiro de 2018 Estabelece os requisitos técnicos para apresentação de consulta à CTNBio sobre as Técnicas Inovadoras de Melhoramento de Precisão.s

Commission on Genetic Modification (2006) New techniques in plant biotechnology. COGEM Report CGM/061024-02

Conko G, Kershen D, Miller H, Parrott W (2016) A risk-based approach to the regulation of genetically engineered organisms. Nat Biotechnol 34:493-503. https://doi.org/10.1038/nbt.3568

CoverCress Inc. (n.d.). https://covercress.com/. Cited 12 Apr 2021

Crippa M, Solazzo E, Guizzardi D, Monforti-Ferrario F, Tubiello FN, Leip A (2021) Food systems are responsible for a third of global anthropogenic GHG emissions. Nature Food 2:198-209

De Jong P, Bertolotto E, De Seze I (2018) From farm to fork: the regulatory status of non-GMO plant innovations under current EU law. Bio-Science Law Review 16(6)

Dederer H-G, Hamburger D (2019) Regulation of genome editing in plant biotechnology - a comparative analysis of regulatory frameworks of selected countries and the EU. Springer Nature, Cham, p 13. https:// doi.org/10.1007/978-3-030-17119-3

Department of Health, Commonwealth of Australia (2018) Third review of the National Gene Technology Scheme. Final Report October 2018. https://www1.health.gov.au/internet/main/publishing.nsf/ Content/gene-technology-review

Department of Health, Commonwealth of Australia (2020) National Gene Technology Scheme, Consultation Regulatory Impact Statement (CRIS) - modernizing and future-proofing the National Gene Technology Scheme: proposed regulatory framework to support implementation of the Third Review. December 2020. https:// consultations.health.gov.au/best-practice-regulation/genetechnology-scheme-cris/

Deutsch CA, Tewksbury JJ, Tigchelaar M, Battisti DS, Merrill SC, Huey RB, Naylor RS (2018) Increase in crop losses to insect pests in a warming climate. Science 361(6405):916-919. https://doi.org/10. 1126/science.aat3466

Doebley JF, Gaut BS, Smith BD (2006) The Molecular genetics of crop domestication. Cell 127(7):1309-1321. https://doi.org/10.1016/j. cell.2006.12.006

Ellens KW, Levac D, Pearson C, Savoie A, Strand N, Louter J, Tibelius C (2019) Canadian regulatory aspects of gene editing technologies. Transgenic Res. 28:165-168. https://doi.org/10.1007/s11248-01900153-2

Entine J, Felipe MSS, Groenewald JH et al (2021) Regulatory approaches for genome edited agricultural plants in select countries and jurisdictions around the world. Transgenic Res. https://doi.org/10.1007/ s11248-021-00257-8

Eriksson D, Kershen D, Nepomuceno A, Pogson BJ, Prieto H, Purnhagen K, Smyth S, Wesseler J, Whelan A (2019) A comparison of the EU regulatory approach to directed mutagenesis with that of other jurisdictions, consequences for international trade and potential steps forward. New Phytol 222(4):1673-1684. https://doi.org/10.1111/ nph. 15627

European Academies' Science Advisory Council EASAC (2018) EASAC and the new plant breeding techniques EASAC and the New Plant Breeding Techniques | EASAC - Science Advice for the Benefit of Europe

European Commission, DG Research and Innovation (2017) Explanatory Note $02 / 2017$ on 'new techniques in agricultural biotechnology'. 
https://ec.europa.eu/info/publications/new-techniques-agriculturalbiotechnology en

European Commission, SWD (2021) 92 Study on the status of new genomic techniques under Union law and in light of the Court of Justice ruling in Case C-528/16. https://ec.europa.eu/food/plant/ gmo/modern_biotech/new-genomic-techniques_en

European Court of Justice (2018) Judgment of the Court of Justice of 25 July 2018. Confédération Paysanne and Others v. Premier Ministre and Ministre de L'Agriculture, de l'Agroalimentaire et de la Forêt. Case C-528/16. ECLI:EU:C:2018:583

European Parliament (2001) Directive 2001/18/EC (2001) of the European Parliament and of the Council of 12 March 2001 on the deliberate release into the environment of genetically modified organisms and repealing Council Directive 90/220/EEC OJ L 2001.106:1-39. https://eur-lex.europa.eu/legal-content/EN/TXT/? uri=celex\%3A32001L0018

Fernie AR, Yan J (2019) De Novo Domestication: an alternative route toward new crops for the future. Mol. Plant. 12(5):615-631. https:// doi.org/10.1016/j.molp.2019.03.016

Food and Agricultural Organization, IFAD, UNICEF, WFP, WHO (2020) The State of Food Security and Nutrition in the World 2020. Transforming food systems for affordable healthy diets. FAO, IFAD, UNICEF, WFP, WHO, Rome. https://doi.org/10. 4060/ca9692en

Fraley RT, Rogers SG, Horsch RB, Sanders PR, Flick JS, Adams SP, Bittner ML, Brand LA, Fink CL, Fry JS, Galluppi GR, Goldberg SB, Hoffmann NL, Woo SC (1983) Expression of bacterial genes in plant cells. Proc Natl Acad Sci USA 80(15):4803-4807

Friedrichs S, Takasu Y, Kearns P, Dagallier B, Oshima R, Schofield J, Moreddu C (2019) An overview of regulatory approaches to genome editing in agriculture. Biotechnol Res Innov 3(2):208-220. https://doi.org/10.1016/j.biori.2019.07.001

Fritsche S, Poovaiah C, MacRae E, Thorlby G (2018) A new zealand perspective on the application and regulation of genome editing. Front. Plant Sci. 9:1323. https://doi.org/10.3389/fpls.2018.01323

FSANZ (2016) Product exemptions from allergen labelling. FSANZ 2016 Food Standard Code - Standard 1.2.3. https://www. foodstandards.gov.au/consumer/foodallergies/Pages/Allergenlabelling-exemptions.aspx. Cited (4 May 2021)

García-Alonso M, Holt K (2020) Fostering innovation in agriculture through enabling regulatory policy. Available via Agricultural Biotechnology Council. https://www.yumpu.com/en/document/ $\mathrm{read} / 63606665 / \mathrm{abc}$-innovation-in-agriculture-report-jan-20-final

Gatica-Arias A (2020) The regulatory current status of plant breeding technologies in some Latin American and the Caribbean countries. Plant Cell, Tissue and Organ Culture 141:229-242. https://doi.org/ 10.1007/s11240-020-01799-1

GBD (2017) Diet Collaborators (2019) Health effects of dietary risks in 195 countries, 1990-2017: a systematic analysis for the Global Burden of Disease Study 2017. The Lancet 393:1958-1972. https://doi.org/10.1016/S0140-6736(19)30041-8

Graham N, Patil GB, Bubeck DM, Dobert RC, Glenn KC, Gutsche AT, Kumar S, Lindbo JA, Maas L, May GD, Vega-Sanchez ME, Stupar RM, Morrell PL (2020) Plant genome editing and the relevance of off-target changes. Plant Physiology 183(4):1453-1471. https://doi. org/10.1104/pp.19.01194

Hamburger D (2019) Comparative analysis: the regulation of plants derived from genome editing in Argentina, Australia, Canada, the European Union, Japan and the United States. In: Dederer H-G, Hamburger D (eds) Regulation of Genome Editing in Plant Biotechnology. Springer, pp 313-363. https://crispr-gene-editingregs-tracker.geneticliteracyproject.org/wp-content/uploads/2020/ 03/2019_Book_RegulationOfGenomeEditingInPlantBiotech.pdf

Hancock JF (2012) Plant evolution and the origin of crop species. CABI
Hanlon PR, Frestedt J, Magurany K (2017) GRAS from the ground up: review of the interim pilot program for GRAS notification. Food Chem Tox. 105:140-150. https://doi.org/10.1016/j.fct.2017.03.064

Haun W, Coffman A, Clasen BM, Demorest ZL, Lowy A, Ray E, Retterath A, Stoddard T, Juillerat A, Cedrone F, Mathis L, Voytas DF, Zhang F (2014) Improved soybean oil quality by targeted mutagenesis of the fatty acid desaturase 2 gene family. Plant Biotechnology Journal 12(7):934-940. https://doi.org/10.1111/pbi. 12201

Hazardous Substances and New Organisms (Organisms Not Genetically Modified) Regulations 1998, amended (2016), r 3(1)(ba). https:// www.legislation.govt.nz/regulation/public/1998/0219/latest/whole. html. Cited 12 Apr 2021

Hazardous Substances and New Organisms Act 1996. (1996) Section 2A. https://www.legislation.govt.nz/act/public/1996/0030/93.0/ DLM381222.html. Cited 12 Apr 2021

Health Canada (2021) Consultation: proposed new guidance for Novel Food Regulations focused on plant breeding. March 25, 2021. https://www.canada.ca/en/health-canada/programs/consultationguidance-novel-foods-regulation-plant-breeding.html. Cited 12 Apr 2021

Herrera-Estrella L, Depicker A, Van Montagu M, Schell J (1983) Expression of chimaeric genes transferred into plant cells using a Ti-plasmid-derived vector. Nature 303:209-213

Herrero M, Thornton PK, Mason-D'Croz D et al (2020) Innovation can accelerate the transition toward a sustainable food system. Nature Food 1:266-272

Hoffman NE (2021) Revisions to USDA biotechnology regulations: the SECURE rule. PNAS 118:e2004841118

Iaffaldano BJ, Zhang Y, Cornish K (2016) CRISPR/Cas9 genome editing of rubber producing dandelion Taraxacum kok-saghyz using Agrobacterium rhizogenes without selection. Industrial Crops and Products 89:356-362. https://doi.org/10.1016/j.indcrop.2016.05. 029

Innovative Genomics Institute (n.d.) Genome editing of the staple crop cassava to eliminate toxic cyanogen production. https:// innovativegenomics.org/projects/genome-editing-staple-cropcassava-eliminate-toxic-cyanogen-production/. Cited 12 Apr 2021

Institute of Medicine (US) and National Research Council (US) (1998) The current US Food Safety System. In: Ensuring Safe Food From Production to Consumption. The National Academy Press, Washington, D.C. https://www.ncbi.nlm.nih.gov/books/ NBK209121/. https://www.nap.edu/read/6163/chapter/1

International Atomic Energy Agency (n.d.) Joint FAO/IAEA Mutant Variety Database. https://mvd.iaea.org/. Cited 12 Apr 2021

International Labour Organization (n.d.) Employment in agriculture data. https://data.worldbank.org/indicator/SL.AGR.EMPL.ZS?end= 2019\&start=1991\&view=chart. Cited 12 Apr 2021

Kaiser N, Douches D, Dhingra A, Glenn KC, Herzig PR, Stowe EC, Swarup S (2020) The role of conventional plant breeding in ensuring safe levels of naturally occurring toxins in food crops. Trends in Food Science \& Technology 100:51-66

Karkute SG, Singh AK, Gupta OP, Singh PM, Singh B (2017) CRISPR/ Cas9 mediated genome engineering for improvement of horticultural crops. Front. Plant Sci. 8:1635. https://doi.org/10.3389/fpls.2017. 01635

Kawall K, Cotter J, Then C (2020) Broadening the GMO risk assessment in the EU for genome editing technologies in agriculture. Environ Sci Eur 32:106. https://doi.org/10.1186/s12302-020-00361-2

Kershen DL (2015) Sustainability council of New Zealand Trust v. the Environmental Protection Authority: gene editing technologies and the law. GM Crops \& Food 6:216-222. https://doi.org/10.1080/ 21645698.2015.1122859

Kitomi Y, Hanzawa E, Kuya N, Inoue H, Hara N, Kawai S, Kanno N, Endo M, Sugimoto K, Yamazaki T, Sakamoto S, Sentoku N, Wu J, Kanno H, Mitsuda N, Toriyama K, Sato T, Uga Y (2020) Root angle 
modifications by the DRO1 homolog improve rice yields in saline paddy fields. PNAS 117(35):21242-21250. https://doi.org/10.1073/ pnas. 2005911117

Komen J, Tripathi L, Mkoko B, Ofosu DO, Oloka H, Wangari D (2020) Biosafety regulatory reviews and leeway to operate: case studies from sub-Sahara Africa. Front Plant Sci. 11:130. https://doi.org/10. 3389/fpls.2020.00130

Ladics GS, Bartholomaeus A, Bregitzer P, Doerrer NG, Gray A, Holzhauser T, Jordan M, Keese P, Kok E, Macdonald P, Parrott W, Privalle L, Raybould A, Rhee SY, Rice E, Romeis J, Vaughn J, Wal JM, Glenn K (2015) Genetic basis and detection of unintended effects in genetically modified crop plants. Transgenic Research 24(4):587-603

Lenser T, Theißen G (2013) Molecular mechanisms involved in convergent crop domestication. Trends in Plant Science 18(12):704-714. https://doi.org/10.1016/j.tplants.2013.08.007

Leopoldina et al. (2019). Towards a scientifically justified, differentiated regulation of genome edited plants in the EU. German National Academy of Sciences Leopoldina, the Union of the German Academies of Sciences and Humanities and the German Research Foundation. Detailview (leopoldina.org)

Louwaars N (2019) 5. Food safety and plant breeding - why are there no problems in practice? In: Urazbaeva A, Szajkowska A, Wernaart B, Franssens NT, Vaskoska RS (eds) The Functional Field of Food Law. Academic Publishers, Wageningen, pp 89-101

Lynn J (2018) UC Berkeley students use CR ISPR to edit the flavor of this common food. https://scet.berkeley.edu/uc-berkeley-crispr-editflavor/. Cited 12 Apr 2021

Maliszewski E (2021) Gene editing offers potential solution to orange growers struggling against citrus greening disease. https:// geneticliteracyproject.org/2021/01/18/gene-editing-offers-potentialsolution-to-orange-growers-struggling-against-citrus-greeningdisease/. Cited 12 Apr 2021

Malnoy M, Viola R, Jung M-H, Koo OJ, Kim S, Velasco R, Kanchiswamy CN (2016) DNA-free genetically edited grapevine and apple protoplast using CRISPR/Cas9 ribonucleoproteins. Front. Plant Sci. 7:1904. https://doi.org/10.3389/fpls.2016.01904

McHughen A (2016) A critical assessment of regulatory triggers for products of biotechnology: product vs. process. GM Crops Food 7:125-158. https://doi.org/10.1080/21645698.2016.1228516

Meijaard E, Brooks TM, Carlson KM, Slade EM, Garcia-Ulloa J, Gaveau DLA, Lee JSH, Santika T, Juffe-Bignoli D, Struebig MJ, Wich SA, Ancrenaz M, Koh LP, Zamira N, Abrams JF, Prins HHT, Sendashonga CN, Murdiyarso D, Furumo PR, Macfarlane N, Hoffmann R, Persio M, Descals A, Szantoi Z, Sheil D (2020) Nature Plants 6:1418-1426. https://doi.org/10.1038/s41477-02000813-w

Menz J, Modrzejewski D, Hartung F, Wilhelm R, Sprink T (2020) Genome edited crops touch the market: a view on the global development and regulatory environment. Front. Plant Sci. 11:586027. https://doi.org/10.3389/fpls.2020.586027

MHLW (2020). https://www.mhlw.go.jp/content/000704532.pdf

Mickelson D (2020) Precision-Bred Alfalfa. Hay \& Forage Grower:1415.

Moose SP, Mumm RH (2008) Molecular plant breeding as the foundation for 21st century Crop Improvement. Plant Physiol. 147(3):969-977

National Academies of Sciences, Engineering, and Medicine (2016) Genetically engineered crops: experiences and prospects. The National Academies Press, Washington, DC. https://doi.org/10. $17226 / 23395$

National Research Council (1987) Introduction of recombinant DNAengineered organisms into the environment: key issues. The National Academies Press, Washington, DC

National Research Council (1989) Field testing genetically modified organisms: framework for decisions. The National Academies Press, Washington, DC
Nepomuceno AL, Fuganti-Pagliarini R, Felipe MSS, Molinari HBC, Velini ED, Pinto ERDC, Dagli MLZ, Filho GA, Fernandes PMB (2020) Brazilian biosafety law and the new breeding technologies. Frontiers of Agricultural Science and Engineering 7(2):204-210. https://doi.org/10.15302/J-FASE-2019301

Office of the Gene Technology Regulator (2016) Technical Review of the Gene Technology Regulations 2001 - discussion paper: options for regulating new technologies (October 2016). http://www.ogtr.gov. a u / in ternet/og tr/publishing.ns f/Content/ 977EF3D4FDD4552ECA2580B10014663C/\$File/Discussion\% 20 Paper $\% 20$ - $\% 20$ Review $\% 20$ of $\% 20$ the $\% 20$ Gene $\%$ 20Technology\%20Regulations\%20.pdf

Office of the Gene Technology Regulator (2019) Gene technology amendment (2019 Measure No. 1) Regulations 2019. http://www. ogtr.gov.au/internet/ogtr/publishing.nsf/content/amendments+to+ the+regs +2019

Ogura T, Goeschl C, Filiault D, Mirea M, Slovak R, Wolhrab B, Satbhai SB, Busch W (2019) Root system depth in arabidopsis is shaped by EXOCYST70A3 via the dynamic modulation of auxin transport. Cell 178(2):400-412. https://doi.org/10.1016/j.cell.2019.06.021

Peng A, Chen S, Lei T, Xu L, He Y, Wu L, Yao L, Zou X (2017) Engineering canker-resistant plants through CRISPR/ Cas9targeted editing of the susceptibility gene CsLOB1 promoter in citrus. Plant Biotechnology Journal 15(12):1509-1519. https://doi.org/ 10.1111/pbi. 12733

Plant Genetic Resources International Platform. The EU court case on mutagenesis (C-528/16). (2019). https://www.pgrip.org/the-eucourt-case-on-mutagenesis-c-528-16/. Cited 12 Apr 2021

Queensland University of Technology (n.d.). https://www.qut.edu.au/ news?id=173568. Cited 12 Apr 2021

Ricepedia (n.d.). http://ricepedia.org/rice-as-food/the-global-staple-riceconsumers\#: :text=Rice $\% 20$ is $\% 20$ the $\% 20$ staple $\% 20$ food, $20 \%$ $25 \% 20$ of $\% 20$ their\%20daily\%20calories. Cited 12 Apr 2021

Rodriguez-Leal D, Lemmon ZH, Man J, Bartlett ME, Lippman ZB (2017) Engineering quantitative trait variation for crop improvement by genome editing. Cell 171(2):470-480.e8. https://doi.org/10. 1016/j.cell.2017.08.030

Sánchez MA (2020) Chile as a key enabler country for global plant breeding, agricultural innovation, and biotechnology. GM Crops \& Foods 11:130-139. https://doi.org/10.1080/21645698.2020. 1761757

Sánchez-León S, Gil-Humanes J, Ozuna CV, Giménez MJ, Sousa C, Voytas DF, Barro F (2018) Low-gluten, nontransgenic wheat engineered with CRISPR/Cas9. Plant Biotechnology Journal 16(4):902-910. https://doi.org/10.1111/pbi.12837

Schmidt SM, Belisle M, Frommer WB (2020) The evolving landscape around genome editing in agriculture. EMBO Rep 21(6):e50680. https://doi.org/10.15252/embr.202050680

Schnell J, Steele M, Bean J, Neuspiel M, Girard C, Dormann N, Pearson C, Savoie A, Bourbonnière L, Macdonald P (2015) A comparative analysis of insertional effects in genetically engineered plants: considerations for pre-market assessments. Transgenic Res 24:1-17. https://doi.org/10.1007/s11248-014-9843-7

Searchinger T, Waite R, Hanson C, Ranganathan J (2019) Creating a sustainable food future - a menu of solutions to feed nearly 10 billion people by 2050 . World Resources Institute, July 2019. https:// research.wri.org/sites/default/files/2019-07/WRR_Food_Full_ Report_0.pdf

Secretariat of the Convention on Biological Diversity (2003). Biosafety and the environment, an introduction to the Cartagena protocol on biosafety. United Nations Environment Programme. Montreal, QC. https://wedocs.unep.org/bitstream/handle/20.500.11822/9993/cpbsunep-cbd-en.pdf? sequence $=1 \&$ isAllowed $=\mathrm{y}$

Southern Agricultural Council (CAS) (2019) Communication to the world trade organization committee on sanitary and phytosanitary measures. Ministerial Declaration of the Southern Agricultural 
Council (CAS) on Gene Editing Techniques. G/SPS/GEN/1699. https:/docs.wto.org/dol2fe/Pages/SS/directdoc.aspx?filename=t:/ G/SPS/GEN1699.docx\&Open=True

Sowa S, Twardowski T, Woźniak E, Zimny T (2021) Legal and practical challenges to authorization of gene edited plants in the EU. New Biotech. 60:183-188. https://doi.org/10.1016/j.nbt.2020.10.008

Soyk S, Lemmon ZH, Oved M, Zamir D, Eshed Y, Lippman ZB (2017) Bypassing negative epistasis on yield in tomato imposed by a domestication gene. Cell 169:1142-1155. https://doi.org/10.1016/j. cell.2017.04.032

Soyk S, Müller NA, Park SJ, Schmalenbach I, Jiang K, Hayama R, Zhang L, Van Eck J, Jiménez-Gómez JM, Lippmann ZB (2016) Variation in the flowering gene SELF PRUNING $5 \mathrm{G}$ promotes day-neutrality and early yield in tomato. Nature Genetics 49:162-168. https://doi. org/10.1038/ng.3733

Stanic M, Hickerson NMN, Arunraj R, Samuel MA (2021) Gene-editing of the strigolactone receptor $\mathrm{BnD} 14$ confers promising shoot architectural changes in Brassica napus (canola). Plant Biotechnol J. 19: 639-641. https://doi.org/10.1111/pbi.13513

Sun Y, Jiao G, Liu Z, Zhang X, Li J, Guo X, Wenming D, Du J, Francis F, Zhao Y, Xia L (2017) Generation of high-amylose rice through CRISPR/Cas9-mediated targeted mutagenesis of starch branching enzymes. Front. Plant Sci. 8:298. https://doi.org/10.3389/fpls. 2017.00298

Tagliabue G (2016) The EU legislation on "GMOs" between nonsense and protectionism: an ongoing Schumpeterian chain of public choices. GM Crops \& Food 8:57-73. https://doi.org/10.1080/ 21645698.2016.1270488

Thygesen P (2019) Clarifying the regulation of genome editing in Australia: situation for genetically modified organisms. Transgenic Res. 28(2):151-159. https://doi.org/10.1007/s11248-019-00151-4

Tsuda M, Watanabe KN, Ohsawa R (2019) Regulation status of genomeedited organisms under the Japanese Cartagena Act. Front. Bioeng. Biotechnol. 7:387. https://doi.org/10.3389/fbioe.2019.00387

Turnbull C, Lillemo M, Hvoslef-Eide TAK (2021) Global regulation of genetically modified crops amid the gene edited crop boom - a review. Front. Plant Sci. 12:630396. https://doi.org/10.3389/fpls. 2021.630396

United Nations (2015) Sustainable Development Goals. https://www.un. org/sustainabledevelopment/sustainable-development-goals/. Cited 12 Apr 2021

United Nations (2020) The Sustainable Development Goals Report 2020. https://unstats.un.org/sdgs/report/2020/The-SustainableDevelopment-Goals-Report-2020.pdf. Cited 12 Apr 2021

United States Environmental Protection Agency (2020) Minimum risk pesticide: definition and product confirmation. https://www.epa. gov/minimum-risk-pesticides/minimum-risk-pesticide-definitionand-product-confirmation\#confirm. Cited 8 April 2021. EPA notes "The producer is responsible to carefully read the criteria and make an evaluation of how the product meets (or does not meet) the criteria."

United States Environmental Protection Agency (n.d.-a) 40 CFR Section 152.6 Substances excluded from regulation by FIFRA. https://www.govinfo.gov/content/pkg/CFR-2019-title40-vol26/pdf/ CFR-2019-title40-vol26-sec152-6.pdf. Cited 12 Apr 2021

United States Environmental Protection Agency (n.d.-b) 40 CFR Section 152.25(f) Minimum Risk Pesticides. https://www.epa.gov/ minimum-risk-pesticides/conditions-minimum-risk-pesticides. Cited 12 Apr 2021

United States Food and Drug Administration (1992) Food for human consumption and animal drugs, feeds, and related products: foods derived from new plant varieties; policy statement, Federal Register. Vol. 57 No. 104, p 22984

United States Food and Drug Administration (2017) Standards for the growing, harvesting, packing, and holding of produce for human consumption: what you need to know about the FDA regulation: guidance for industry small entity compliance guide. Exemptions in Section 112.2. https://www.fda.gov/media/107298/download. Cited 4 May 2021

United States Food and Drug Administration (2020) Eligibility for classification as generally recognized as safe (GRAS). Criteria found at 21 CFR $\$ 570.30$. https://www.govinfo.gov/app/details/CFR-2020title21-vol6/CFR-2020-title21-vol6-sec570-30. Cited 12 Apr 2021

United States Food and Drug Administration (n.d.) Acrylamide and Diet, Food Storage, and Food Preparation. https://www.fda.gov/food/ chemicals/acrylamide-and-diet-food-storage-and-food-preparation. Cited 12 Apr 2021

USDA AMS (n.d.) Federal Seed Act. https://www.ams.usda.gov/rulesregulations/fsa. Cited 12 Apr 2021

USDA APHIS (2014) Confirmation that [low acrylamidepotatoes are not regulated articles. https://www.aphis.usda.gov/biotechnology/ downloads/reg_loi/aphis_response_cellectis_potato.pdf. Cited 12 Apr 2021

USDA APHIS (2020a) 7 CFR Parts 330, 340, and 372. Movement of certain genetically engineered organisms. Final Rule. May 18, 2020. Federal Register 85(96):289790

USDA APHIS (2020b) Confirmation that corn with enhanced yield potential is not a regulated article. https://www.aphis.usda.gov/ biotechnology/downloads/reg_loi/20-168-20_air_response_signed. pdf. Cited 7 Apr 2021

USDA APHIS (2020c) Confirmation that remontant strawberries developed with CRISPR/Cas9 are not regulated articles. https://www. aphis.usda.gov/biotechnology/downloads/reg_loi/20-168-05_air_ inquiry_a1_cbidel.pdf

USDA APHIS (2020d) Confirmation that non-browning avocado is not a regulated article. https://www.aphis.usda.gov/biotechnology/ downloads/reg_loi/20-168-35_air_response_signed.pdf. Cited 7 Apr 2021

USDA APHIS (2020e) Confirmation of the regulatory status of genome edited potato with reduced PPO and reduced glycoalkaloids. https:// www.aphis.usda.gov/biotechnology/downloads/reg_loi/20-16806 air response signed.pdf

USDA APHIS (2020f) Confirmation of the regulatory status of genome edited avocado with reduced PPO. https://www.aphis.usda.gov/ biotechnology/downloads/reg_loi/20-168-35_air_response_signed. pdf

USDA APHIS (2020g) Confirmation of the regulatory status of genome edited potato with reduced PPO. https://www.aphis.usda.gov/ biotechnology/downloads/reg_loi/20-168-01_air_response_signed. pdf

USDA APHIS (2020h) Confirmation that low PPO5 potatoes are not a regulated article. https://www.aphis.usda.gov/biotechnology/ downloads/reg loi/16-320-01 air response signed.pdf

USDA APHIS (2020i) Confirmation that PPO KO Potato is not a regulated article. https://www.aphis.usda.gov/biotechnology/ downloads/reg loi/16-090-01 air response signed.pdf. Cited 7 Apr 2021

USDA APHIS (2020j) Confirmation that Brassica juncea (L.) with improved flavor is not a regulated article. https:/www.aphis.usda.gov/ biotechnology/downloads/reg_loi/20-168-07_air_response_signed. pdf. Cited 7 Apr 2021

USDA APHIS (2020k) Confirmation that tomato with increased gammaaminobutyric acid (GABA) is not a regulated article. https://www. aphis.usda.gov/biotechnology/downloads/reg_loi/20-140-01_air_ response signed.pdf. Cited 7 Apr 2021

USDA APHIS (20201) Confirmation that high oleic low linolenic soybean is not a regulated article. https://www.aphis.usda.gov/ biotechnology/downloads/reg_loi/20-066-01-air-response-signed. pdf. Cited 7 Apr 2021

USDA APHIS (2020m) Confirmation that nutritionally-enhanced wheat is not a regulated article. https://www.aphis.usda.gov/ 
biotechnology/downloads/reg_loi/17-038-01_air_response_signed. pdf. Cited 12 Apr 2021

USDA APHIS (2020n) Confirmation of the regulatory status of CRISPR/ Cas9 genome edited Thlaspi arvense L. (pennycress) lines. https:// www.aphis.usda.gov/biotechnology/downloads/reg loi/19-34601_air_response_signed.pdf. Cited 12 Apr 2021

USDA APHIS (2020o) Confirmation of the regulatory status of genomeedited CRISPR mutagenized Thlaspi arvense L. (pennycress) lines https://www.aphis.usda.gov/biotechnology/downloads/reg_loi/19218-01 air response signed.pdf. Cited 12 Apr 2021

USDA APHIS (2021) Guidance for preparing proposals to exempt plants with additional modifications from regulation pursuant to $7 \mathrm{CFR} \S$ 340.1(b)(4). January 19, 2021. https://www.aphis.usda.gov/ biotechnology/downloads/brs-guidance-document.pdf. Cited 8 Apr 2021

USDA FAS (2019a). Environment ministry finalizes policy for regulating genome editing. GAIN Report JA9024. https://www.fas.usda.gov/ data/japan-environment-ministry-finalizes-policy-regulatinggenome-editing. Cited 12 Apr 2021

USDA FAS (2019b) MAFF guidance for the handling of genome edited organisms under the Cartagena Act. GAIN Report JA2019-0196. https://apps.fas.usda.gov/newgainapi/api/Report/ DownloadReportByFileName?fileName $=$ MAFF $\% 20$ Guidance $\%$ 20 for $\% 20$ the $\% 20$ Handling $\% 20$ of $\% 20$ Genome $\% 20$ Edited $\%$ 20Organisms $\% 20$ under\%20the $\% 20$ Cartagena\%20Act_Tokyo_ Japan 11-15-2019

USDA FAS (2019c) Review process confirmed for GE food derived from genome editing. GAIN Report No. JA9056. https://apps.fas.usda. gov/newgainapi/api/report/downloadreportbyfilename?filename $=$ Review\%20Process $\% 20$ Confirmed $\% 20$ for $\% 20$ GE $\% 20$ Food $\%$ 20Derived $\% 20$ from $\% 20$ Genome $\% 20$ Editing Tokyo Japan 5-312019.pdf. Cited 12 Apr 2021

USDA FAS (2019d) Japanese Health Ministry Finalizes Genome Edited Food Policy. GAIN Report JA9050. https://apps.fas.usda.gov/ newgainapi/api/report/downloadreportbyfilename?filename= Japanese $\% 20$ Health\%20Ministry\%20Finalizes \%20Genome\% 20Edited\%20Food\%20Policy Tokyo Japan 4-12-2019.pdf. Cited 12 Apr 2021

USDA FAS (2020) Final MAFF guidelines for the handling of genome edited feed and feed additives. GAIN Report JA2020-0060. https:// a p s.fas.usda.gov/newgainapi/a pi/Report/ DownloadReportByFileName? fileName $=$ Final $\% 20$ MAFF\% 20Guidelines $\% 20$ for $\% 20$ the $\% 20$ Handling $\% 20$ of $\% 20$ Genome $\%$ 20Edited $\% 20$ Feed $\% 20$ and $\% 20$ Feed $\% 20$ Additives $\% 20$ Tokyo Japan_03-22-2020. Cited 12 Apr 2021

USDA FAS (2021) Government of Nigeria approved National Biosafety Guideline of Gene Editing. GAIN Report NI2021-0001. https:// apps.fas.usda.gov/newgainapi/api/Report/
DownloadReportByFileName?fileName $=$ Government $\% 20 \mathrm{of} \%$ $20 \mathrm{Nigeria} \% 20$ approved $\% 20 \mathrm{National} \% 20 \mathrm{Biosafety} \%$ 20Guideline $\% 20$ on\%20Gene\%20Editing_Lagos_Nigeria_02-082021. Cited 12 Apr 2021

Van der Meer P, Angenon G, Bergmans H, Buhk HJ, Callebaut S, Chamon M, Eriksson D, Gheysen G, Harwood W, Hundleby P, Kearns P, Mcloughlin T, Zimny T (2020) The status under EU law of organisms developed through novel genomic techniques. Eur J Risk Regulation 2021:1-20. https://doi.org/10.1017/err. 2020.105

Venske E, dos Santos RS, Busanello C, Gustafson P, Costa de Oliveira A (2019) Bread wheat: a role model for plant domestication and breeding. Hereditas 156:16. https://doi.org/10.1186/s41065-019-0093-9

Vives-Vallés JA, Collonnier C (2020) The judgment of the CJEU of 25 July 2018 on mutagenesis: interpretation and interim legislative proposal. Front. Plant Sci. 10(03 March 2020). https://doi.org/10.3389/ fpls.2019.01813

Walkowiak S, Gao L, Monat C et al (2020) Multiple wheat genomes reveal global variation in modern breeding. Nature 588:277-283. https://doi.org/10.1038/s41586-020-2961-x

Whelan A, Lema MA (2015) Regulatory framework for gene editing and other new breeding techniques (NBTs) in Argentina. GM Crops \& Food 6(4):253-265. https://doi.org/10.1080/21645698.2015. 1114698

Whelan AI, Gutti P, Lema MA (2020) Gene editing regulation and innovation economics. Front. Bioeng. Biotechnol. 8:303. https://doi.org/ $10.3389 /$ fbioe. 2020.00303

Yuste-Lisbona FJ, Fernández-Lozano A, Pineda B, Bretones S, OrtízAtienza A, García-Sogo B, Müller NA, Angosto T, Capel J, Moreno V, Jiménez-Gómez JM, Lozano R (2020) ENO regulates tomato fruit size through the floral meristem development network. PNAS 117(14):8187-8195. https://doi.org/10.1073/pnas. 1913688117

Zess E, Begemann M (2021) CRISPR-Cas9 and beyond: what's next in plant genome engineering. In Vitro Cellular \& Developmental Biology - Plant, this volume

Zhou X, Jacobs TB, Xue L-J, Harding SA, Tsai C-J (2015) Exploiting SNPs for biallelic CRISPR mutations in the outcrossing woody perennial Populus reveals 4-coumarate:CoA ligase specificity and redundancy. New Phytol. 208(2):298-301. https://doi.org/10.1111/ nph. 13470

Zhu H, Li C, Gao C (2020) Applications of CRISPR-Cas in agriculture and plant biotechnology. Nature Reviews Molecular Cell Biology 21:661-677

Zimny T, Eriksson D (2020) Exclusion or exemption from risk regulation? A comparative analysis of proposals to amend the EU GMO legislation. EMBO Rep 21:e51061. https://doi.org/10.15252/embr. 202051061 